\title{
Water Conservation Education in Elementary Schools: The Case of the Nenetzingo River Catchment, Mexico
}

\author{
Guadalupe Yolanda Valenzuela-Morales ${ }^{1}$, Marivel Hernández-Téllez ${ }^{1}$, María de Lourdes Ruiz-Gómez ${ }^{2}$, \\ Miguel Angel Gómez-Albores ${ }^{1}\left[\right.$, Ricardo Arévalo-Mejía ${ }^{1}$ and Carlos Alberto Mastachi-Loza ${ }^{1, *(1)}$
}

1 Instituto Interamericano de Tecnología y Ciencias del Agua (IITCA), Universidad Autónoma del Estado de México, Toluca 50000, Mexico; gvalenzuelam508@alumno.uaemex.mx (G.Y.V.-M.);

mhernandezt@uaemex.mx (M.H.-T.); magomeza@uaemex.mx (M.A.G.-A.); ricarevalom@gmail.com (R.A.-M.)

2 Laboratorio de Ecología y Conducta, Facultad de Ciencias, Universidad Autónoma del Estado de México,

Toluca 50000, Mexico; mlruizg@uaemex.mx

* Correspondence: camastachil@uaemex.mx

\section{check for}

updates

Citation: Valenzuela-Morales, G.Y; Hernández-Téllez, M.; Ruiz-Gómez, M.d.L.; Gómez-Albores, M.A.; Arévalo-Mejía, R.; Mastachi-Loza, C.A. Water Conservation Education in Elementary Schools: The Case of the Nenetzingo River Catchment,

Mexico. Sustainability 2022, 14, 2402. https://doi.org/10.3390/ su14042402

Academic Editor: Marzena Smol

Received: 21 January 2022

Accepted: 17 February 2022

Published: 19 February 2022

Publisher's Note: MDPI stays neutral with regard to jurisdictional claims in published maps and institutional affiliations.

Copyright: (c) 2022 by the authors. Licensee MDPI, Basel, Switzerland. This article is an open access article distributed under the terms and conditions of the Creative Commons Attribution (CC BY) license (https:// creativecommons.org/licenses/by/ $4.0 /)$.

\begin{abstract}
Water is one of the primary resources for humans; however, clean water available for consumption is a constant problem worldwide. Nonetheless, environmental education is fundamental to promote social consciousness and orientate people to improve water management, and children are the main target as they are prone to adopt long-lasting habits. Therefore, this study aimed to implement an environmental education program on water conservation in 10-year-old students from two rural communities within the Nenetzingo River catchment in Mexico. The study was a three-step methodology that included diagnostics, education, and evaluation. It was found that the students that participated in the educational program enriched their knowledge, attitudes, and perception towards water. Therefore, implementing environmental education programs in young students can improve water use and conservation in Mexico. Additionally, the design used in this research allows identifying the target groups for immediate intervention.
\end{abstract}

Keywords: environmental attitudes; water conservation; environmental education; behavioral changes; sustainable societies

\section{Introduction}

Water is a critical resource for human survival because many crucial activities depend on its availability. As the first United Nations World Water Development Report states "of all the social and natural crises that humanity faces, the water crisis has the most harmful effect on survival and sustainability in the planet" [1]. Recently, water scarcity has become a global problem that can be the result of either water resource depletion or poor management to provide it. Particularly, deficient integrated water resources management is one of the main environmental problems that pose a harmful effect on society [2]. On the face of this, environmental education is fundamental to promote social consciousness orientated to the protection, conservation, and sustainable water management. The development of environmental education programs is a worldwide necessity and may become a powerful tool to build sustainable societies [3,4].

Although most interventions have been implemented in developed countries, and more frequently in urban rather than in rural areas [5], the water problems of urban populations may not be as critical. It has also been established that educational projects are more efficient when the interventions focus on children and young people because they are faster learners and the habits adopted early in life persist until adulthood [6,7]. Furthermore, several authors have pointed out that children and youngsters can be effective change agents within their homes and communities [8-11].

Mexico is a country with median water availability, although with severe water overexploitation and pollution problems [12,13]. Additionally, the knowledge regarding water 
is deficient; therefore, it is of paramount importance to orientate and educate the population about the importance of water conservation in order to have environmentally responsible [14], more conscious, educated, and involved citizens [15]. With the preventive nature of environmental education, changes in day-to-day habits and behavior can be translated into actions focused on environmental protection and particularly, water conservation $[16,17]$. Consciousness, appreciation, and participation of the community will impact the effectiveness of the conservation actions implemented.

Therefore, the main aims of this study were to determine the actual level of knowledge, attitudes, and perceptions about conservation water and to evaluate the effectiveness of an educational intervention to increase them in elementary school students (10 years old) from rural communities of central Mexico.

\section{Materials and Methods}

\subsection{Study Area}

The Nenetzingo River catchment is located in the southeast of the state of Mexico (Figure 1). According to the IAHRIS index report, it is an altered basin [18] that belongs to a region vulnerable to droughts that has experienced periods of rainfall scarcity in the last ten years [19]. The catchment comprises 14 rural communities that share many sociodemographic characteristics, but with particular hydric problems. The research was carried out in the localities of Ahuacacatitlán and San Miguel Laderas (Figure 1), both dealing with different challenges respect to water availability. Ahuacatitlán is located upstream in the catchment, $90 \%$ of the housing in the area lacks a drinking water service and none of them have a sewage system. In general, the inhabitants build artisanal wells to meet their water necessities throughout the year. On the other hand, San Miguel Laderas is in the middle region of the catchment; here, all the houses lack potable water and sewage services [20]. Water is supplied by the government every week, filling a water tank per household with potable water at a cost of around USD 45. This makes people ration and administrate water more efficiently.

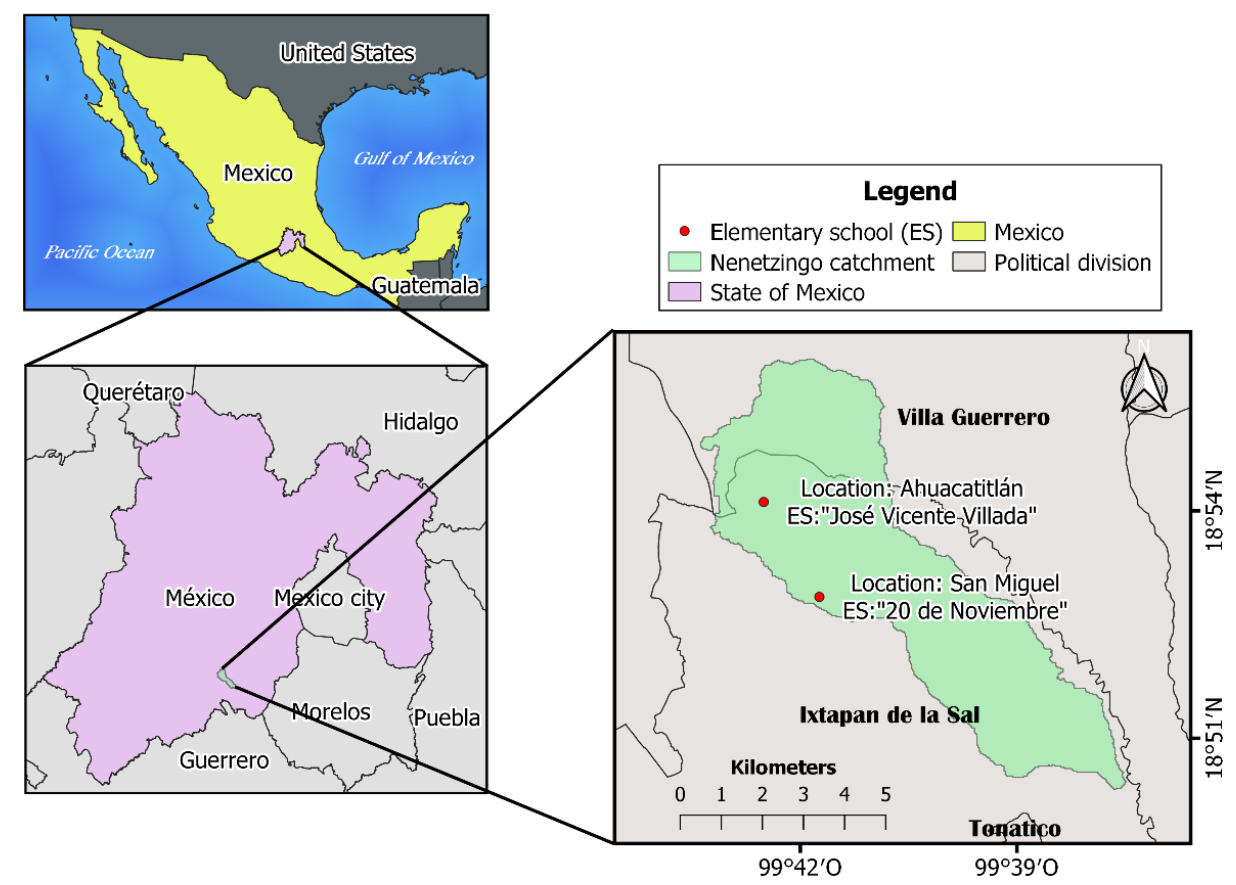

Figure 1. The Nenetzingo River catchment is located in the southeast of the state of Mexico. At the municipality level, it is a shared catchment covering the north and northeast regions of Ixtapan de la Sal and the south of Villa Guerrero, Mexico. 


\subsection{Subjects}

Since the program aimed to contextualize and strengthen the knowledge about water conservation that students have already attained in school, fifth-grade scholars were selected, because according to the curriculum for the basic education in Mexico (SEP), they already have basic knowledge about the subject [21]. Additionally, in Mexico students in the fifth year are generally between the ages of 10 and 11, and it is known that children of this age tend to acquire and process knowledge more easily, and are prone to share it within their family circle [22]. It is important to note that in the study area there are only two primary schools, with only one group of students for each grade; hence, we worked the total fifth-grade population from each community. The primary schools are "José Vicente Villada" and "20 de Noviembre" from the communities Ahuacatitlán and San Miguel Laderas, respectively. The "José Vicente Villada" school had at the time 27 students with an average age of 9.8 years, $59 \%$ were girls and $41 \%$ boys. In the "20 de Noviembre" school, there were 19 students with an average age of 10.7 years, 52\% were girls and $48 \%$ were boys. All subjects gave their informed consent for inclusion before they participated in the study. The study was conducted in accordance with the Declaration of Helsinki and approved by a local Ethics committee.

\subsection{Study Design}

The study was carried out in three phases: (1) Diagnostics. Students from both sites answered a test (pre-test) to identify their level of knowledge about water conservation. (2) Intervention. An educational environmental program was developed and executed. From the results of the pre-test, we selected the school with the lowest level of knowledge and the less favorable attitudes towards the use and care of water, since it was considered more convenient and necessary to carry out the educational intervention there. The last phase was (3) Evaluation. At the end of the educational intervention, the same test (post-test) was applied in the two schools, to examine whether the group exposed to the intervention improved their knowledge and attitudes towards water at least to the same level as the school with the best scores in the pre-test.

Additionally, a post-test was applied to the community that received the educational intervention (3-month post-test), in order to determine whether the acquired knowledge during the educational intervention remained in the student's medium-term memory.

The test covered three dimensions: knowledge, attitudes, and perception about water conservation. The research was performed from a quantitative perspective, and data were collected with a self-made instrument (Supplementary Materials).

\subsection{Educational Intervention}

The educational intervention comprised seven sessions, delivered weekly from September to November 2017. Since the length of this kind of intervention may cause distraction, each session only lasted $90 \mathrm{~min}$ (630 $\mathrm{min}$ in total) and covered different topics (Table 1) [10,23]. Although the educational program was developed by all authors, it was only applied by V-M. To identify and select the topics used in the educational intervention, the official elementary school curriculum, and studies on environmental education were revised. This revision was important to identify the level of knowledge that students should already possess regarding the use, care, and conservation of water; hence, the intervention could reinforce the knowledge that students had already acquired at school. 
Table 1. Topic framework for the educational intervention about water conservation.

\begin{tabular}{|c|c|c|c|c|}
\hline Session & Su & & Dimension & Education Strategy \\
\hline 1 & $\begin{array}{l}\text { a. } \\
\text { b. } \\
\text { c. }\end{array}$ & $\begin{array}{l}\text { Water in the Earth } \\
\text { The water cycle } \\
\text { Physical and chemical water } \\
\text { characteristics }\end{array}$ & Knowledge & $\begin{array}{l}\text { Video, diagrams, pictures, and } \\
\text { exposition. }\end{array}$ \\
\hline 2 & $\begin{array}{l}\text { a. } \\
\text { b. } \\
\text { c. }\end{array}$ & $\begin{array}{l}\text { Water availability } \\
\text { What is a basin? } \\
\text { Water availability in the community }\end{array}$ & Knowledge/Perception & $\begin{array}{l}\text { Children's story, model of } \\
\text { catchment and exposition. }\end{array}$ \\
\hline 3 & $\begin{array}{l}\text { a. } \\
\text { b. } \\
\text { c. }\end{array}$ & $\begin{array}{l}\text { Importance of water for the environment, } \\
\text { plants, fauna, and humans } \\
\text { Water contents in food and live organisms } \\
\text { Water properties (surface tension, } \\
\text { capillarity, and solvent action) }\end{array}$ & Knowledge/Attitude & Video, pictures, and experiments. \\
\hline 4 & $\begin{array}{l}\text { a. } \\
\text { b. } \\
\text { c. } \\
\text { d. }\end{array}$ & $\begin{array}{l}\text { Water use } \\
\text { Water pollution } \\
\text { Where does used water go to? } \\
\text { Water treatment alternatives (wetlands) }\end{array}$ & Knowledge/Attitude & $\begin{array}{l}\text { Educational game, children's } \\
\text { story, and song. }\end{array}$ \\
\hline 5 & $\begin{array}{l}\text { a. } \\
\text { b. } \\
\text { c. }\end{array}$ & $\begin{array}{l}\text { Measures to use water efficiently } \\
\text { Types of water } \\
\text { Re-use of "gray waters" }\end{array}$ & Attitude/Knowledge & $\begin{array}{l}\text { Exposition, diagrams, video and } \\
\text { make an artificial wetland. }\end{array}$ \\
\hline 6 & $\begin{array}{l}\text { a. } \\
\text { b. }\end{array}$ & $\begin{array}{l}\text { Healthy habits-healthy } \\
\text { people-healthy communities } \\
\text { Water resources management }\end{array}$ & Attitude/Perception & Children's story and exposition. \\
\hline 7 & $\begin{array}{l}\text { a. } \\
\text { b. } \\
\text { c. }\end{array}$ & $\begin{array}{l}\text { Rainwater collection systems } \\
\text { Rainwater use } \\
\text { Methods of purifying water at home and } \\
\text { safe storage }\end{array}$ & Attitude/Knowledge & $\begin{array}{l}\text { Exposition, draws, and } \\
\text { infographics. }\end{array}$ \\
\hline
\end{tabular}

\subsection{Test Design Assessment}

A pre- and a post-test approach to assessing change in knowledge, perception, and attitudes were performed (Supplementary Materials). The tests included thirteen "knowledge" questions (Q1-Q13) consisting of multiple-choice questions. The first nine questions measured the student's general understanding of water, whereas the following four questions were covered during the educational intervention. The maximum score for the knowledge questions was 13 points. Students' attitudes were assessed with five questions (Q14-Q18), some of them modified from [24]. An unfavorable attitude meant that students considered that it is not important to care about water, or that they do not care for it at all, and that within their family circle they are not worried about sustainable use of water. For this, students were asked to indicate their level of agreement or disagreement with the sentences on a Likert-type scale with three categories (Yes, Sometimes, and No). The maximum score for the attitude section was 3.75 points. Finally, perception was analyzed with one open question aimed to determine the students' perceptions towards water.

\subsection{Data Analysis}

Data normality was assessed with a Shapiro-Wilk test and the confidence level and the homogeneity were evaluated with the Levene test. To determine the effectiveness of the educational intervention a simple paired t-test was performed to compare the pre-test, post-test, and the 3-month post-test for Ahuacatitlán. A t-test for independent samples was used to compare the pre-test and post-test and the level of knowledge between Ahuacatitlán 
and San Miguel Laderas. All statistical analyses were performed in IBM SSPS (V. 23) at a confidence level of $95 \%$.

Attitude data was analyzed using a Likert scale with three categories (Yes, Sometimes, and No) [25-28] because it is easier for kids to discriminate between them [29]. Following Hernández et al. (2014), a rank score was assigned to each category; from 0 to 1.25 represented students with unfavorable attitudes towards water care, from 1.26 to 2.50 represented students with favorable attitudes, whereas 2.52 to 3.75 (the maximum score achieved during the tests) represented students with very favorable attitudes towards water. Finally, for the perception dimension, the answers to water problems are described.

\section{Results}

The Shapiro-Wilk test indicated that the data behaved parametrically (Table 2).

Table 2. Shapiro-Wilk test from the pre and post-test in two rural communities of the Nenetzingo River catchment in Mexico.

\begin{tabular}{ccccc}
\hline Test & Group & Statistic & Fd & $p$ \\
\hline \multirow{2}{*}{ Pre-test } & Ahuacatitlán & 0.95 & 27 & 0.26 \\
& San Miguel Laderas & 0.93 & 19 & 0.25 \\
\hline \multirow{2}{*}{ Post-test } & Ahuacatitlán & 0.96 & 27 & 0.54 \\
& San Miguel Laderas & 0.94 & 19 & 0.30 \\
\hline
\end{tabular}

\subsection{Knowledge}

The community of San Miguel Laderas showed the best level of knowledge during the pre-test; for this reason, only Ahuacatitlán received the educational intervention (Table 3).

Table 3. Comparisons of the mean scores of the knowledge section between Ahuacatitlán and San Miguel Laderas before (pre-test) the educational intervention.

\begin{tabular}{cccccc}
\hline Test & Group & M (Sd) & $p$ Levene & fd & $p$ \\
\hline \multirow{2}{*}{ Pre-test } & Ahuacatitlán & $6.18(1.82)$ & \multirow{2}{*}{0.230} & \multirow{2}{*}{44} & 0.013 \\
& San Miguel Laderas & $7.49(1.50)$ & & & \\
\hline
\end{tabular}

The initial knowledge scores (pre-test) for Ahuacatitlán increased after the educational intervention (pre-test vs. post-test $\mathrm{t}(27)=6.14, p<0.001$ ), and were also higher after three months (pre-test vs. 3-month post-test $\mathrm{t}(27)=5.33, p<0.001$ ). The knowledge gained right after the intervention remained similar 3 months post-test (post-test vs. 3-month post-test $t$ $(27)=1.315, p=0.20)$ (Figure 2).

On the other hand, for San Miguel Laderas there was no change in knowledge pre and post-test $(\mathrm{t}(19)=0.38, p=0.70)$ (Figure 3 ).

We found that after the water conservation program, Ahuacatitlán students improved their knowledge towards water, even significantly surpassing the group with the initial highest level of knowledge (San Miguel Laderas) (Table 4).

Table 4. Comparisons of the knowledge mean scores between Ahuacatitlán and San Miguel Laderas after an educational intervention program in Ahuacatitlán (post-test).

\begin{tabular}{cccccc}
\hline Test & Group & M (Sd) & $p$ Levene & fd & $p$ \\
\hline \multirow{2}{*}{ Post-test } & Ahuacatitlán & $8.62(1.43)$ & \multirow{2}{*}{0.417} & \multirow{2}{*}{44} & 0.043 \\
& San Miguel Laderas & $7.64(1.75)$ & & & \\
\hline
\end{tabular}




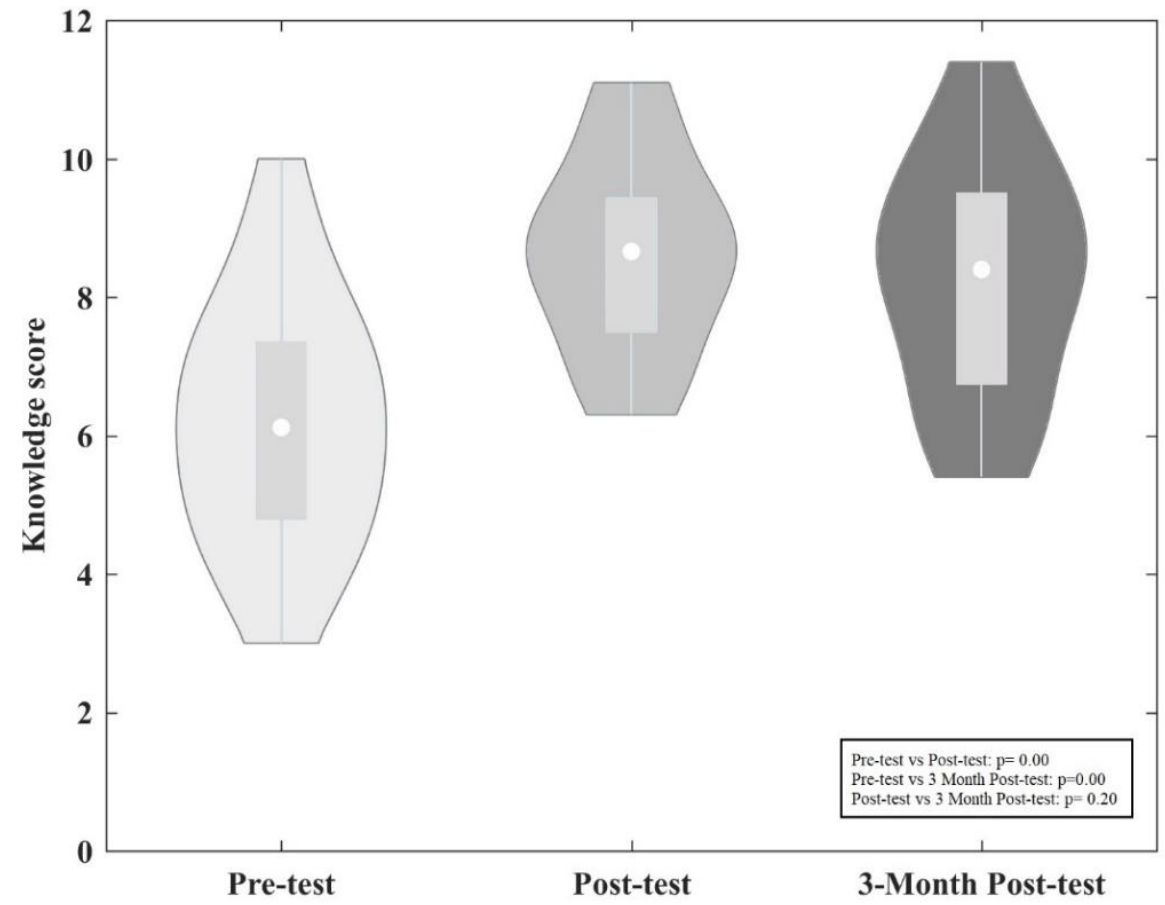

Figure 2. Violinplot of the distribution of the knowledge scores for Ahuacatitlán before (pre-test), right after (post-test), and 3 months after the educational intervention (3-month post-test). Inside of each violinplot, a boxplot summarizes the ranges and individual medians (white dots).

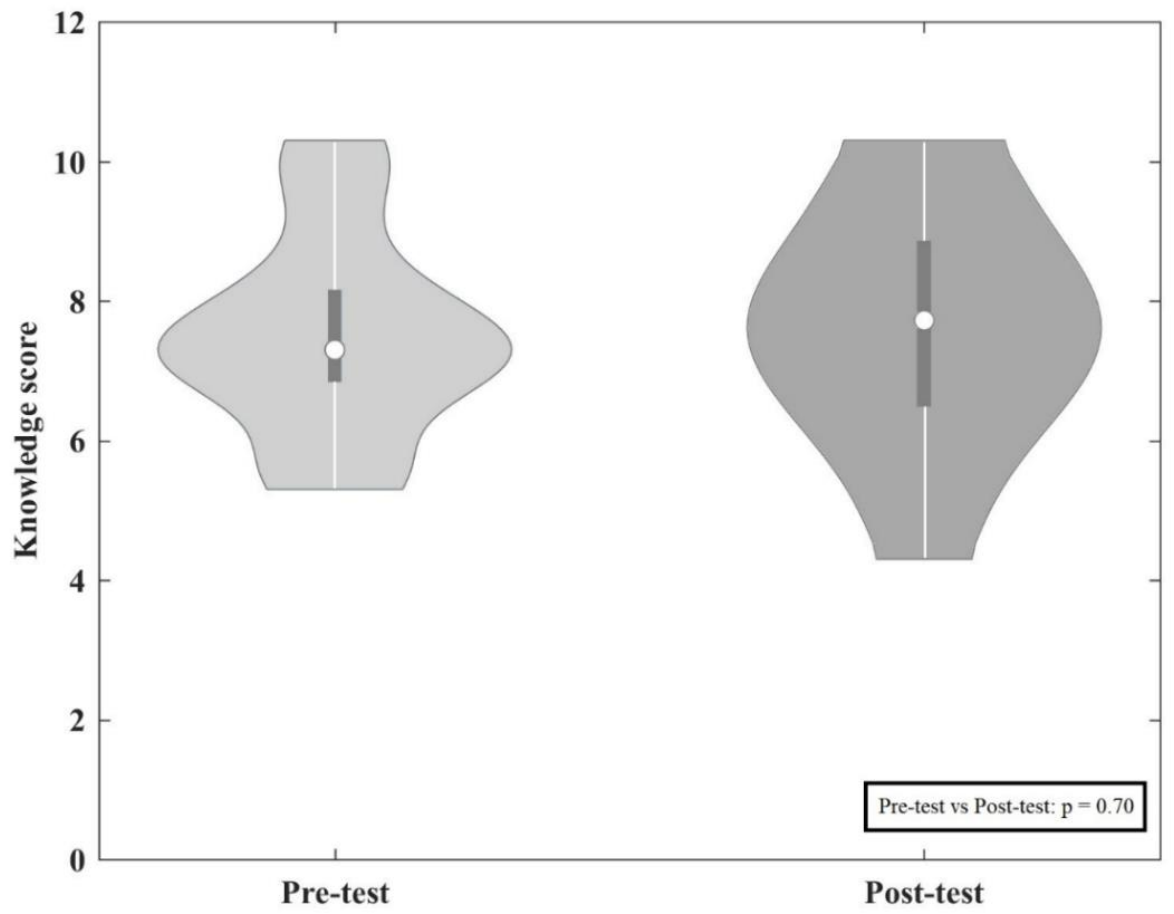

Figure 3. Violinplot of the distribution of the knowledge scores for San Miguel Laderas pre-test and post-test. Inside of each violinplot, a boxplot summarizes the ranges and individual medians (white dots).

\subsection{Attitude}

According to the Likert scale, after the educational intervention, students from Ahuacatitlán improved their attitudes towards water, showing an increased percentage of stu- 
dents with favorable attitudes. However, the percentage of students attaining unfavorable attitudes towards water in this community remained the same before and after the intervention. On the other hand, students from San Miguel Laderas showed only favorable and very favorable attitudes during both the pre and the post-test (Figure 4).
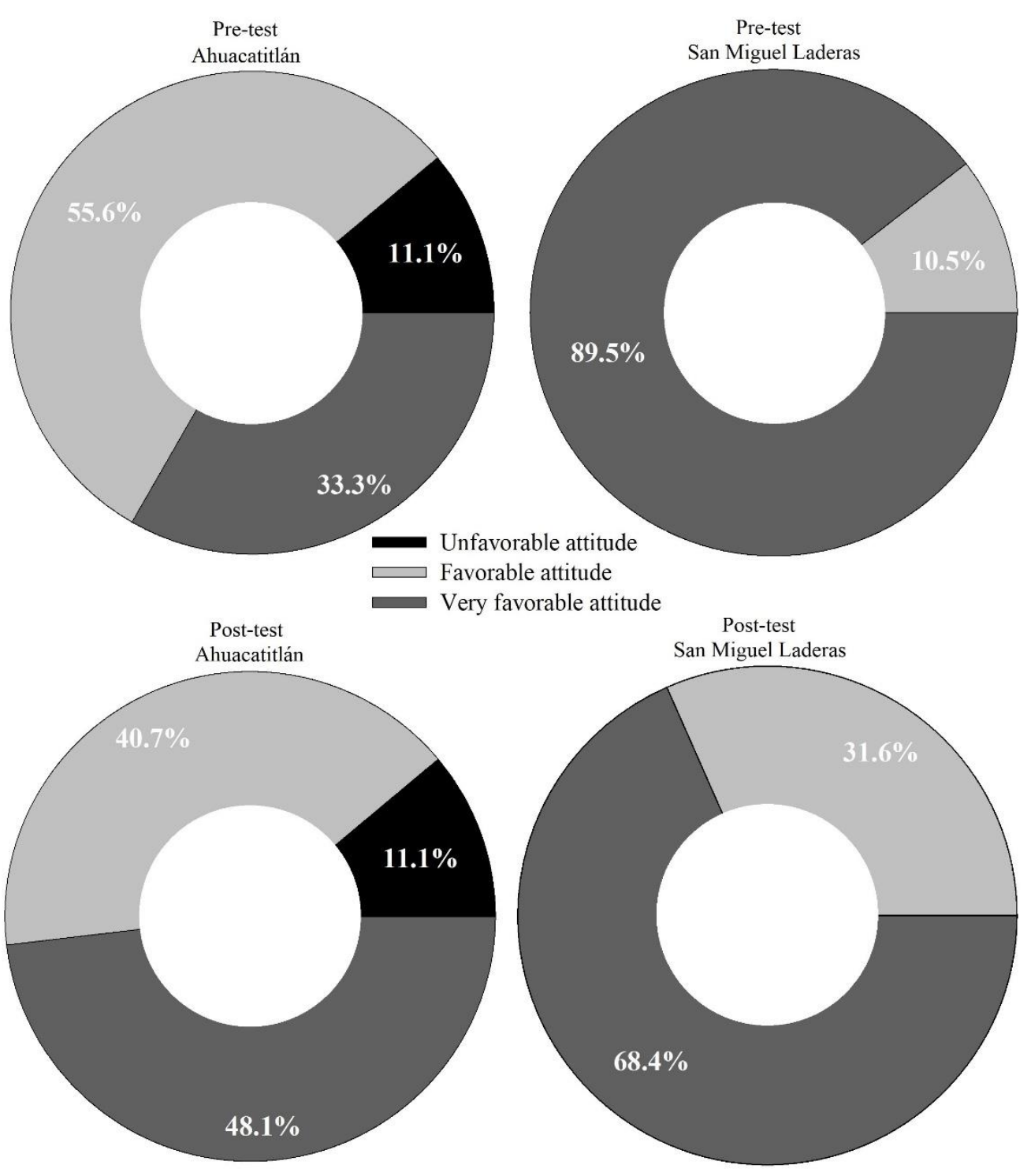

Figure 4. Attitudes towards water shown by students from Ahuacatitlán and San Miguel Laderas before (pre-test) and after an educational intervention about knowledge, attitudes, and perception regarding water conservation (post-test) in Ahuacatitlán. The results represent the percentage of students in each attitude category.

\subsection{Perception}

It was considered relevant to follow up the answers to Q20 (perception) in both communities as both have differential access to water, because their perceptions towards problems related to the resource may differ. It was found that students in both sites believe that there are problems related to water in their communities. Interestingly, the responses that prevailed in Ahuacatitlán were "We do not take care of water", "We pollute water", "During the dry season there is no water". On the other hand, the students from San Miguel Laderas mentioned "Not everybody has access to drinking water", "Sometimes there are 
no water pipes available to supply water to households". A summary of the answers is presented in Table 5.

Table 5. Summary of the answers on the student's perceptions towards problems related to water in Ahuacatitlán and San Miguel Laderas before and after an educational intervention about knowledge, attitudes, and perception regarding water conservation in Ahuacatitlán.

\begin{tabular}{|c|c|c|c|}
\hline \multirow{3}{*}{ Question } & \multirow{3}{*}{ Answer } & \multicolumn{2}{|c|}{ Perception } \\
\hline & & Ahuacatitlán & San Miguel Laderas \\
\hline & & Post-Test & Post-Test \\
\hline $\begin{array}{l}\text { Q20. Do you } \\
\text { think that there } \\
\text { are problems in } \\
\text { your community } \\
\text { related to water? }\end{array}$ & Yes * & $\begin{array}{l}\text { - Sometimes there is no water in the river channel } \\
\text { - We do not care about water } \\
\text { - There is no drinking water } \\
\text { - During the dry season there is no water } \\
\text { - During the dry season people fight over water } \\
\text { - There is no water in some places } \\
\text { - We do not harvest water or care about it }\end{array}$ & $\begin{array}{l}\text { - Not everybody has access to drinking water } \\
\text { - We do not reuse water } \\
\text { - People wastewater } \\
\text { - Not everybody cares about water } \\
\text { - Sometimes water is not supplied every } \\
\text { week by the government }\end{array}$ \\
\hline
\end{tabular}

* Yes was the most common answer pre and post-test in both groups.

\section{Discussion}

In this study, we evaluated the effectiveness of an environmental educational intervention regarding water conservation in fifth-grade students from two rural communities of central Mexico that face different challenges regarding water availability. Both sites lack potable water and sewage systems; however, they greatly differ in water availability. Ahucatitlán relies on artisanal wells; therefore, water availability varies temporally because during the dry season there is a shortage of the resource. On the other hand, San Miguel Laderas depends on Municipal management for which every week they receive potable water at a cost. All students evaluated were from the same grade and of similar age and there was gender equity; therefore, we assumed that they should have the same level of knowledge about water from school. However, at the start of the study students from Ahucacatitlán had the lowest knowledge and showed fewer positive attitudes towards water use and care compared to San Miguel Laderas' students. Hence, Ahucacatitlán was selected to implement an educational intervention, as some authors have suggested that this kind of program should be given to the population showing the lowest level of knowledge [28]. We believe that such findings are the result of both localities having different environmental, social, and family factors related not only to water but also to education itself, which resulted in a different level of knowledge about water [30,31]. Among those factors are the fact that they are thought by different teachers with different teaching-learning techniques, there is a variation in the number of students in each school, etc. Additionally, situations such as parental care, study habits, housing conditions, absences of the teacher or the students, illnesses, school abandonment, among others can play an important role in the knowledge that students attain. For example, in Ahuacatitlán, the school's principal mentioned that she makes home visits to ask students to return to school, sometimes students go back; however, that is not always the case.

After $630 \mathrm{~min}$ of activities covering several subjects related to water (Table 4), students from Ahucacatitlán improved their knowledge about water, attained better scores than San Miguel Laderas, and retained this knowledge three months after the educational intervention (3-month post-test). It has to be taken into account that it was not convenient to apply the 3-month post-test in San Miguel Laderas because they did not receive the educational intervention. The results here are in line with other studies showing that the knowledge about the use, care, and importance of water can improve after a short environmental education intervention [5-7,10,32]. Students from San Miguel Laderas showed a degree of consistency in their level of knowledge about water during the pre and post-tests, which has also been found in similar studies $[6,33]$. These results somehow can 
be used as a control, implying that the school itself did not have an effect on the level of knowledge about water in all students and that the intervention was successful.

Regarding attitudes, in Ahucacatitlán there was a positive change in which the very favorable attitudes increased by $14.8 \%$ after the educational intervention, demonstrating that attitude can be improved $[5,6,10,33,34]$. Although there were no changes in the percentage of unfavorable attitudes towards water in this community, they were minimal $(11.1 \%)$ in pre- and post-tests. Students from San Miguel Laderas did not show unfavorable attitudes towards water; on the contrary, they showed more very favorable attitudes pre and post-tests than students from Ahucacatitlán.

Although both communities lie within the Nenetzingo River catchment, they face different challenges regarding water availability. It is possible that San Miguel Laderas showed a high percentage of very favorable attitudes towards water since they have to pay to obtain potable water; therefore, people have to dispense carefully and efficiently the resource, whereas Ahucacatitlán has access to water through the construction of artisanal wells. The differences in the characteristics of the communities play an important role since the inequality in the availability of the resource modifies the awareness about the use, care, and importance of water. People that have easier access or have the resource in abundance tend to value it less, not only economically but also socially, compared to people that pay a price to obtain it [35]. Additionally, it is known that the place of residence influences the knowledge and behavior of inhabitants towards the environment [10] and this can be the reason why children from San Miguel Laderas showed higher percentages of favorable and very favorable attitudes in this study. However, a future study should integrate a more comprehensive diagnostic test, to fully understand why students differ in their level of knowledge and attitudes towards water care, and should also include a bigger sample size and more schools, to disentangle the factors that may have had an effect here.

There were also differences in the perception between communities. Although both localities have problems regarding water availability, they solve them in different ways; therefore, the dynamics with respect to water are variable. Previous studies have been shown that perceptions about water depend on factors such as ethnicity, cultural level, age, education, gender, and place of residence [36,37], and that may be the case for the studied communities.

\section{Conclusions}

A pre-test was applied to fifth-grade students (10 years old) from Ahuacatitlán and San Miguel Laderas. The students from Ahuacatitlán showed the lowest level of knowledge, attitudes, and perceptions towards the efficient use and conservation of water, perhaps due to water availability in each site. Therefore, this group participated in an environmental educational intervention.

This first approach demonstrated that evaluating the level of knowledge, attitudes, and perceptions towards water allows hierarchizing populations to implement educational interventions that strengthen the contents of the environmental education programs. Additionally, this also allowed us to determine that the water situation from the site of residence is an important factor to take into account.

After seven sessions of 90 min each, students from Ahuacatitlán improved their knowledge, attitudes, and perceptions towards water conservation, and this was retained 3 months after the educational intervention. Therefore, short environmental education programs like this are successful at increasing knowledge and improving attitudes and positive perceptions towards water use and conservation.

Due to the undeniable water crisis, students from all levels of education and the general public need to improve their views on sustainable water use; therefore, there is a general necessity to implement educational programs aimed to increase people's knowledge, perception, and attitudes towards water. Hence, the design used in this research helps to identify the groups in need of immediate intervention and which the efforts must be directed toward. 
Supplementary Materials: The following supporting information can be downloaded at: https: / / www.mdpi.com/article/10.3390/su14042402/s1, The questionnaire: What do I know about water?

Author Contributions: All authors contributed to the study's conception and design. Conceptualization was performed by G.Y.V.-M., M.H.-T. and M.A.G.-A. Investigation, material preparation, and data collection were performed by G.Y.V.-M. Data curation, formal analysis, methodology, and visualization were performed by G.Y.V.-M., M.d.L.R.-G., M.A.G.-A., R.A.-M. and C.A.M.-L. The supervision was carried out by M.H.-T. and M.A.G.-A. The first draft of the manuscript was written by G.Y.V.-M., M.d.L.R.-G. and C.A.M.-L. All authors have read and agreed to the published version of the manuscript.

Funding: This research was funded by CONACyT grant number (769761) and the APC was funded by [Universidad Autónoma del Estado de México].

Institutional Review Board Statement: The study was conducted in accordance with the Declaration of Helsinki and approved by the Ethics Committee of the Instituto Interamericano de Tecnología y Ciencias del Agua.

Informed Consent Statement: Informed consent was given by the scholar authorities and the parents of the respondents.

Data Availability Statement: The dataset generated for this study is available on request to the corresponding author.

Acknowledgments: First author thanks "Consejo Nacional de Ciencia y Tecnología" (CONACyT) of Mexico for the master's scholarship (769761).

Conflicts of Interest: The authors declare that they have no conflict of interest.

\section{References}

1. UNESCO. Water for People, Water for Life: Executive Summary of the UN World Water Development Report; UNESCO Publishing and BERGHAHN Books: Paris, Francia, 2003.

2. Monforte, G.M.; Cartú, P.C.C. Escenario del agua en México. Cult. Científica Tecnol. 2015, 30, 31-40.

3. Contreras, K.; Contreras, J.; Corti, M.; De Sousa, J.; Durán, M.; Escalante, M. El Agua Un Recurso Para Preservar; Universidad de Los Ángeles: Mérida, Venezuela, 2008.

4. Zsóka, Á.; Szerényi, Z.M.; Széchy, A.; Kocsis, T. Greening Due to Environmental Education? Environmental Knowledge, Attitudes, Consumer Behavior and Everyday pro-Environmental Activities of Hungarian High School and University Students. J. Clean. Prod. 2013, 48, 126-138. [CrossRef]

5. Middlestadt, S.; Grieser, M.; Hernández, O.; Southwell, B.; Schwartz, R. Turning Minds on an Faucets off: Water Conservation Education in Jordanian Schools. J. Environ. Educ. 2001, 32, 37-45. [CrossRef]

6. Aird, A.; Tomera, A. The Effects of a Water Conservation Instructional Unit on the Values Held by Sixth Grade Students. J. Environ. Educ. 1977, 9, 31-42. [CrossRef]

7. Birch, S.K.; Schwaab, K.E. The Effects of Water Conservation Instruction on Seventh-Grade Students. J. Environ. Educ. 1983, 14, 26-31. [CrossRef]

8. UNICEF. Educación Sobre El Cambio Climático y El Medio Ambiente; UNICEF: New York, NY, USA, 2012.

9. Damerell, P.; Howe, C.; Milner-Gulland, E.J. Child-Orientated Environmental Education Influences Adult Knowledge and Household Behaviour. Environ. Res. Lett. 2013, 8, 015016. [CrossRef]

10. Kinder, T.; Mesner, N.O.; Larese, M.; Lott, K.H.; Cachelin, A.; LaLonde, K. Changes in knowledge and attitude from a short-term aquatic education program. Nat. Sci. Educ. 2015, 44, 18-25. [CrossRef]

11. Menn, A. SSWM (Sustainable Sanittation and Water Management Toolbox). School Campaigns. Available online: https://sswm. info/humanitarian-crises/urban-settings/hygiene-promotion-community-mobilisation/important/school-campaigns-\%2 $8 \mathrm{dc} \% 29$ (accessed on 20 January 2019).

12. Calixto, R. Las Representaciones Sociales Del Uso Del Agua; COMIE: México, México, 2009.

13. Rodríguez, N.; Ruiz, O.; Fajersson, P. Acciones y reflexiones para la conservación y el manejo del agua en México. Cienc. Adm. 2010, 1, 11-16.

14. Frantz, C.M.; Mayer, F.S. The Importance of Connection to Nature in Assessing Environmental Education Programs. Stud. Educ. Eval. 2014, 41, 85-89. [CrossRef]

15. Val Segura, R.; Quiroz Vara, L. Cultura Del Agua; Primera, IMTA: Morelos, México, 2016.

16. Avendaño, W.R. La Educación Ambiental (EA) Como Herramienta de la Responsabilidad Social (RS). Revista Luna Azul 2012 $35,94-115$. 
17. Márquez, D. De la Teoría a la Práctica En Educación Ambiental: El Caso Del Agua. In En Memorias Del Congreso Agua y Educación Ambiental: Nuevas Propuestas Para la Acción; Alicante, Spain, 2003; Available online: https://agua.org.mx/wp-content/uploads/ 2012/03/aguayeducacionnuevaspropuestasparalaaccion.pdf\#page=16 (accessed on 20 January 2019).

18. Arévalo-Mejía, R.; Leblois, E.; Salinas-Tapia, H.; Mastachi-Loza, C.; Bâ, K.; Díaz-Delgado, C. A Baseline Assessment of Hydrologic Alteration Degree for the Mexican Catchments at Gauged Rivers (2016). Sci. Total Environ. 2020, 729, 139041. [CrossRef] [PubMed]

19. Meza-González, R.A.; Ibañez-Hernández, O.F. Análisis de propuestas metodológicas sobre vulnerabilidad contenidas en los programas de medidas preventivas y de mitigación de la sequía de México. Tecnociencia Chihuah. 2015, 3, 180-191.

20. Manzano-Solís, L.R.; Díaz-Delgado, C.; Gómez-Albores, M.A.; Mastachi-Loza, C.A.; Soares, D. Use of Structural Systems Analysis for the Integrated Water Resources Management in the Nenetzingo River Watershed, Mexico. Land Use Policy 2019, 87, 104029. [CrossRef]

21. Flores-Camacho, F. La Enseñanza de la Ciencia En la Educación Básica En México; INEE: México, México, 2012.

22. Vermeersch, T.M. How Do We Educate Children That Live in a Water Rich Environment about the Need for Water Conservation? School of Education and Leadership Student Capstone Theses and Dissertations, Hamline University, St Paul, MN, USA, 2016.

23. Bogner, F.X. The influence of short-term outdoor ecology education on long-term variables of enviromental perspective. J. Environ. Educ. 1998, 24, 17-29. [CrossRef]

24. Rodríguez, M. de los A. Intervención Didáctica: Vamos a Cuidar El Agua En $5^{\circ}$ Grado; Universidad pedagógica veracruzana y Secretaria de educación de Veracruz: Veracruz, México, 2010.

25. García Sánchez, J.; Aguilera Terrats, J.R.; Castillo Rosas, A. Guía Técnica Para la Construcción de Escalas de Actitud. Odiseo Rev. Electrónica Pedagog. 2011.

26. Mendieta Hernández, M.P.; Gutiérrez Gómez, G.L. Enviromental Attitudes toward Water, an Exploration in Students from the Ventaquemada Municipality (Bocayá). Luna Azul 2014, 39, 40-62. [CrossRef]

27. Moreira-Segura, C.; Araya-Rodríguez, F.; Charpentier-Esquivel, C. El Agua Como Parte de la Cultura de Las Comunidades Rurales: Un Análisis Para la Cuenca Del Río San Carlos. Rev. Tecnol. Marcha 2015, 28, 126-140. [CrossRef]

28. Yu, X. Is Environment 'a City Thing'in China? Rural-Urban Differences in Environmental Attitudes. J. Environ. Psychol. 2014, 38, 39-48.

29. Hernández, S.R.; Fernández, C.C.; Baptista, L.P. Metodología de la Investigación, 6th ed.; Mc Graw Hill: México, México, 2014; ISBN 978-1-4562-2396-0.

30. Villagrá, J.A.M.; Sahelices, C.C. La Metodología Indagatoria En Educación Primaria. Una Mirada Desde la Perspectiva Del Aprendizaje Significativo. In Enseñanza de las Ciencias: Revista de Investigación y Experiencias Didácticas; 2017; pp. 981-988.

31. Bosco, E.B. Factores Escolares Asociados a Los Aprendizajes En la Educación Primaria Mexicana: Un Análisis Multinivel. REICE Rev. Iberoam. Sobre Calid. Efic. Cambio Educ. 2008, 6, 58-84.

32. Smith, S.N.J.; Semrau, H. Evaluation of the enviromental education program at the New Jersey school of conservation. J. Environ. Educ. 2004, 36, 3-18. [CrossRef]

33. Turgut, T.; Metin, Y.; Adnan, T. Educating children on water safety for drowning prevention. Soc. Indic. Res. 2016, 129, 787-801. [CrossRef]

34. Armstrong, J.B.; Impara, J.C. The Impact of an Enviromental Education Program on Knowledge and Attitude. J. Environ. Educ. 1991, 22, 36-40. [CrossRef]

35. Torres, L.B. La Gestión Del Agua Potable En la Ciudad de México: Los Retos Hídricos de la CDMX: Gobernanza y Sustentabilidad; HAL: México, México, 2017.

36. Castrejón, A.M.; Barraza, L.; Mazari, M.; Cuarón, A.D. Conocimientos, Percepciones y Actitudes Acerca del Agua de Niños de México: Su Importancia Para la Educación Ambiental; Fondo Para la Educación ambiental: Veracruz, México, 2015.

37. Wolters, E.A. Attitude-behavior consistency in household water consumption. Soc. Sci. J. 2014, 51, 455-463. [CrossRef] 